\title{
Aeromonas hydrophila associated with mass mortality of adult goldfish Carassius auratus (Linnaeus, 1758) in ornamental farms in India
}

\author{
ARATHI DHARMARATNAM, T. RAJA SWAMINATHAN, RAJ KUMAR AND \\ V. S. BASHEER \\ Peninsular and Marine Fish Genetic Resources Centre, ICAR-National Bureau of Fish Genetic Resources \\ CMFRI Campus, Kochi - 682 018, Kerala, India \\ e-mail: rajathanga@yahoo.co.in
}

\begin{abstract}
Aeromonas hydrophila was identified the causative agent of a disease outbreak in goldfish, Carassius auratus from four ornamental fish farms in Kerala, India. Seven bacterial isolates viz., Plesiomonas shigelloides (NPPS-1), Aeromonas hydrophila (NPAH-1, 2, 3 and 4), Citrobacter freundii (NPCF-1) and Acinetobacter spp. (NPA-1) were isolated from the affected fish. Further, all four $A$. hydrophila (NPAH-1, 2, 3 and 4) isolates were identified by amplification of gyrB and rpoD genes. The RAPD profile using 3 primers confirmed that all four A. hydrophila were genetically similar. No cytopathic effect was observed on goldfish fin (GFF) cell line after inoculation of the tissue homogenate from the affected fish and affected tissues were found negative for koi herpesvirus (KHV), cyprinid herpesvirus-2 (CyHV-2) and spring viraemia of carp virus (SVCV). Experimental challenge resulted in mortality of fish injected with A. hydrophila only. A. hydrophila was observed to be cytotoxic on GFF cell line and exhibited haemolytic activity on 5\% sheep blood agar. A. hydrophila possessed multiple virulence genes viz., enterotoxins, haemolytic toxins and outer membrane protein as determined by PCR. A. hydrophila was sensitive to Cefixime, Chloramphenicol, Nitrofurantoin, Kanamycin, Ciprofloxacin, Furazolidone and Cefixime/Clavulanic acid. After treatment with the suggested antibiotics, the fish were recovered from the disease.
\end{abstract}

Keywords: Aeromonas hydrophila, Antimicrobial resistance, Cytotoxicity, Goldfish, Phylogenetic identification, Virulence genes

\section{Introduction}

Ornamental fish are gaining popularity in India and their farming is becoming popular in many places in the country. The ornamental fish industry in India is rapidly growing at the rate of $20 \%$ per annum (Ayyappan et al., 2006). Noga (2010) has reported that the successful production in fish culture has been hampered by factors like diseases. High stocking levels of ornamental fishes in culture ponds has resulted in various disease outbreaks leading to huge economic losses. Fishes are always exposed to bacterial pathogens in the aquatic environment, which has led to many bacterial infections in aquaculture systems affecting fish production (Omprakasam and Manohar, 1991). A range of pathogenic bacteria such as Aeromonas spp., Bacillus spp., Citrobacter spp., Edwardsiella spp., Flavobacterium spp., Serratia spp., Proteus spp., Vibrio spp., Providencia spp. and Klebsiella spp. have been reported to cause diseases in ornamental fish (Austin and Austin, 2007). Many reports on the bacterial diseases of Indian freshwater fishes have been published earlier (Das et al., 1999; Vivekanandhan et al., 2002; Mohanty and Sahoo, 2007). Kumar et al., (2015) reported mass mortality in ornamental koi carp due to a bacterial pathogen, Proteus hauseri in India.
Goldfish, Carassius auratus (Linnaeus 1758) is a common domesticated ornamental fish in garden ponds and aquaria. A disease outbreak in goldfish during the rainy months of June and July 2015, was detected in an ornamental fish farm in Ernakulam District, Kerala during the routine aquatic animal disease surveillance of ornamental fish farms, under the National Surveillance Programme of Aquatic Animal Diseases (NSPAAD). The disease spread was rapid affecting the goldfish population in the 3 nearby farms also, with a cumulative mortality of $70-90 \%$ over 10 days time in all 4 farms. Clinical signs which were clearly evident in the moribund fish were haemorrhages on the fin, tail and dropsy. The present study investigated the cause of the disease outbreak in goldfish.

\section{Materials and methods}

Sampling

Moribund goldfish specimens ( $\mathrm{n}=45$, body weight, 18-23 g) were transported alive in aerated plastic bags containing water from the pond to the laboratory, from a disease outbreak in four ornamental fish farms sharing water from a common stream in Kerala. and screened for external parasites and other microbial pathogens. Tissue 
samples from gills, fin, heart, kidney and spleen were collected aseptically from 10-12 fish per farm and pooled farm-wise for bacterial isolation. Tissue samples (gills, fin, heart, kidney and spleen) were also collected in tissue culture medium, as well as in $95 \%$ ethanol for screening for viruses.

\section{Screening for viral pathogens from fish samples}

Viral isolation was attempted on goldfish fin (GFF) cell line by inoculating with fish tissue homogenates from affected fish. The internal organs viz., heart, kidney, liver and spleen as well as gills from each of the infected fish was collected aseptically, pooled and homogenised in Leibovitz's 15 (L-15) medium containing antibiotic and antimycotic solution (Gibco, Carlsbad, CA, USA) at a final dilution of $1 / 10$. The tissue homogenate was centrifuged at $3000 \mathrm{~g}, 10 \mathrm{~min}$ at $10^{\circ} \mathrm{C}$ and then the supernatant was filtered using $0.22 \mu \mathrm{m}$ syringe membrane filter (Millipore). The filtered homogenate was inoculated to $80 \%$ confluent GFF cell line in a $25 \mathrm{~cm}^{2}$ flask. The cells were then incubated for $1 \mathrm{~h}$ at room temperature and then supernatant was discarded and replaced with L-15 medium supplemented with 5\% FBS and incubated at $28^{\circ} \mathrm{C}$. The cells were observed for any cytopathic effect (CPE) and 5 blind passages were done. GFF cells and cell culture supernatant were used for extraction of the viral nucleic acids for virus screening. Extraction of RNA/DNA from the inoculated GFF cell line and the affected goldfish tissues was carried out using Gene JET RNA purification kit (Thermo Scientific, Lithuania) and DNAeasy Blood and Tissue Kit (Qiagen, Hilden, Germany) respectively and the manufacturer's instructions were followed for production of quality templates in PCR reactions. Amplification of nucleic acids were carried out using published primers to screen for koi herpesvirus (KHV), goldfish herpesvirus haematopoietic necrosis virus (GHHNV) or cyprinid herpesvirus-2 (CyHV-2) and spring viraemia of carp virus (SVCV). Primer details are listed in Table 1.

\section{Bacterial isolation and analyses}

The organs collected from moribund fish from each farm were pooled separately and homogenised for bacterial isolation. The samples were inoculated into sterile nutrient broth and incubated at $28^{\circ} \mathrm{C}$ for $24 \mathrm{~h}$. The overnight grown culture was then streaked in Trypticase soya agar (HiMedia) plates and was incubated at $28^{\circ} \mathrm{C}$ for $48 \mathrm{~h}$. Different types of bacterial colonies were isolated from all the samples. Bacterial identification was done as per Barrow and Feltham (2004). The results of biochemical tests for different bacteria were compared with corresponding reference strains as described by various authors (Brenner et al., 1993; Krovacek et al., 2000; Constantiniu et al., 2004; Chen et al., 2012). The identified bacterial isolates were stored at $-80^{\circ} \mathrm{C}$ in $20 \%$ $(\mathrm{v} / \mathrm{v})$ glycerol for further use. Extraction of DNA from bacterial isolates were done as described by Miller et al. (1988). The extracted DNA quality and quantity were checked using UV spectrophotometer (Beckman, USA), measuring the optical density (OD) at 260 and $280 \mathrm{~nm}$. All the bacterial strains were identified and confirmed $16 \mathrm{~S}$ rRNA sequencing using the $16 \mathrm{~S}$ rRNA bacterial universal primers and PCR conditions as per Weisburg et al. (1991). Briefly, amplifications were performed in a total volume of $25 \mu \mathrm{l}$ reaction mixture containing $1 \mathrm{X}$ reaction buffer $(50 \mathrm{~mm}$ Potassium Chloride, $10 \mathrm{~mm}$ Tris, $0.01 \%$ gelatin, $\mathrm{pH} 9.0$ ) with $2.0 \mathrm{~mm}$ magnesium chloride (Fermentas), $5 \mathrm{p} \mathrm{mol} \mathrm{each} \mathrm{of} \mathrm{forward} \mathrm{and} \mathrm{reverse}$ primers, $200 \mathrm{~mm}$ dNTPs (Fermentas), 1.5 U Taq DNA polymerase (Fermentas) and template DNA (25 - $50 \mathrm{ng}$ ). The reaction mixture was pre-heated at $94^{\circ} \mathrm{C}$ for $3 \mathrm{~min}$ followed by 30 cycles of $94^{\circ} \mathrm{C}$ for $1.3 \mathrm{~min}$, annealing at $52^{\circ} \mathrm{C}$ for $40 \mathrm{~s}$ and extension at $72^{\circ} \mathrm{C}$ for $1 \mathrm{~min}$. After completion of the reaction. The $\mathrm{PCR}$ products were detected by running a sample from each reaction tube to $1.5 \%$ agarose gel electrophoresis, stained with ethidium bromide and the product size yield was approximately $1450 \mathrm{bp}$. Further, the species-level confirmation of four isolates of $A$. hydrophila was carried out by phylogenetic analysis using gyrB and $\mathrm{rpoD}$ genes. PCR amplification and sequencing for both genes were performed using primer sequences, as described by Martinez-Murcia et al. (2011). PCR amplicons for each primer set were sequenced by Sanger's method at the automated sequencing facility (Scigenom Pvt. Ltd., India). Clustal W in MEGA 5 software (Tamura et al., 2011) was employed for alignment of the partial gene sequences with respective bacterial reference strains. NCBI Basic Local Alignment Search Tool (BLAST) (http://www.ncbi.nlm.nih.gov/) and Ribosomal Database Project (RDP) (http://rdp.cme.msu. edu) were used for molecular identification and homology comparison of $16 \mathrm{~S}$ rRNA sequences as well as the gyrB and $\mathrm{rpoD}$ sequences of the four $A$. hydrophila isolates. The nucleotide sequences of the bacterial isolates obtained were deposited in NCBI GenBank database.

\section{Random amplified polymorphic DNA (RAPD)-PCR analysis}

Genomic DNA was isolated from broth culture of the four $A$. hydrophila isolates at log phase and approximately 30-35 $\mu \mathrm{g}$ of DNA was yielded from $2 \mathrm{ml}$ of each bacterial culture. Out of the 15 decamer random primers $(\mathrm{M} / \mathrm{S}$ Operon Technologies) screened, OPA-2, OPA-3 and OPA-4 
Table 1. Details of the primers used in the study

\begin{tabular}{|c|c|c|c|c|}
\hline Target & Primer sequence & Size (bp) & PCR conditions & Reference \\
\hline A. hydrophila hem & $\begin{array}{l}\text { hemF TCG GGG AAG ATA TGG ATG TT } \\
\text { hemR ATA CAT TGC CAA ACC CTT CG }\end{array}$ & 963 & $\begin{array}{l}35 \text { cycles of: } \\
30 \mathrm{~s}, 94^{\circ} \mathrm{C} \\
30 \mathrm{~s}, 54^{\circ} \mathrm{C} \\
1 \mathrm{~min}, 72^{\circ} \mathrm{C} \\
10 \mathrm{~min}, 72^{\circ} \mathrm{C}\end{array}$ & $\begin{array}{l}\text { Designed in the present } \\
\text { study (AF410466) }\end{array}$ \\
\hline A. hydrophila aerA & $\begin{array}{l}\text { aerF: TGTCGGGGATGACATGAACGTG } \\
\text { aerR: CCAGTTCCAGTCCCACCACTTCA }\end{array}$ & 720 & $\begin{array}{l}35 \text { cycles of: } \\
30 \mathrm{~s}, 94^{\circ} \mathrm{C} \\
30 \mathrm{~s}, 54^{\circ} \mathrm{C} \\
60 \mathrm{~s}, 72^{\circ} \mathrm{C} \\
10 \mathrm{~min}, 72^{\circ} \mathrm{C}\end{array}$ & Wang et al. (2012) \\
\hline A. hydrophila alt & $\begin{array}{l}\text { altF: ATGACCCAGTCCTGGCACGG } \\
\text { altR: GCCGCTCAGGCCGAAGCCGC }\end{array}$ & 480 & $\begin{array}{l}35 \text { cycles of: } \\
30 \mathrm{~s}, 94^{\circ} \mathrm{C} \\
30 \mathrm{~s}, 54^{\circ} \mathrm{C} \\
60 \mathrm{~s}, 72^{\circ} \mathrm{C} \\
10 \mathrm{~min}, 72^{\circ} \mathrm{C}\end{array}$ & Wang et al. (2012) \\
\hline A. hydrophila aha1 & $\begin{array}{l}\text { ahalF: GCCGCTAACGCTGCAGTGGTTTACGAC } \\
\text { ahalR: CGCAGAGGCTAGATTAGAAGTTGTATTG }\end{array}$ & 1087 & $\begin{array}{l}35 \text { cycles of: } \\
30 \mathrm{~s}, 94^{\circ} \mathrm{C} \\
30 \mathrm{~s}, 54^{\circ} \mathrm{C} \\
60 \mathrm{~s}, 72^{\circ} \mathrm{C} \\
10 \mathrm{~min}, 72^{\circ} \mathrm{C}\end{array}$ & Wang et al. (2012) \\
\hline A. hydrophila omp TS & $\begin{array}{l}\text { OmpTSF: GCAGTGGTATATGACAAAGAC } \\
\text { OmpTSR: TTAGAAGTTGTATTGCAGGGC }\end{array}$ & 1002 & $\begin{array}{l}35 \text { cycles of: } \\
1 \mathrm{~min}, 95^{\circ} \mathrm{C} \\
1 \mathrm{~min}, 60^{\circ} \mathrm{C} \\
1 \mathrm{~min}, 72^{\circ} \mathrm{C} \\
10 \mathrm{~min}, 72^{\circ} \mathrm{C}\end{array}$ & $\begin{array}{l}\text { Khushiramani et al. } \\
\text { (2007) }\end{array}$ \\
\hline $\begin{array}{l}\text { Koi herpes virus } \\
\text { (KHV) }\end{array}$ & $\begin{array}{l}\text { TKF- GGGTTACCTGTACGAG } \\
\text { TKR- CACCCAGTAGATTATGC }\end{array}$ & 409 & $\begin{array}{l}40 \text { cycles of: } \\
1 \mathrm{~min}, 95^{\circ} \mathrm{C} \\
1 \mathrm{~min}, 52^{\circ} \mathrm{C} \\
1 \mathrm{~min}, 72^{\circ} \mathrm{C} \\
10 \min , 72^{\circ} \mathrm{C}\end{array}$ & Bercovier et al. (2005) \\
\hline $\begin{array}{l}\text { Spring viraemia of } \\
\text { carp virus (SUCV) }\end{array}$ & $\begin{array}{l}\text { SVCV F1 -TCTTGGAGCCAAATAGCTCARRTC } \\
\text { SVCVR2- AGATGGTATGGACCCCAATACATHACNCAY }\end{array}$ & 714 & $\begin{array}{l}35 \text { cycles of: } \\
1 \mathrm{~min}, 95^{\circ} \mathrm{C} \\
1 \mathrm{~min}, 55^{\circ} \mathrm{C} \\
1 \mathrm{~min}, 72^{\circ} \mathrm{C} \\
10 \min , 72^{\circ} \mathrm{C}\end{array}$ & Stone et al. (2003) \\
\hline $\begin{array}{l}\text { Cyprinid herpesvirus } \\
(2 \mathrm{CyHv}-2)\end{array}$ & $\begin{array}{l}\text { CyHVpolF CCCAGCAACATGTGCGACGG } \\
\text { CyHVpolR CCGTARTGAGAGTTGGCGCA }\end{array}$ & 362 & $\begin{array}{l}40 \text { cycles of } \\
1 \mathrm{~min}, 95^{\circ} \mathrm{C} \\
1 \mathrm{~min}, 55^{\circ} \mathrm{C} \\
1 \mathrm{~min}, 72^{\circ} \mathrm{C} \\
10 \min , 72^{\circ} \mathrm{C}\end{array}$ & Jeffery et al. (2007) \\
\hline
\end{tabular}

were selected for RAPD analyses. The genomic DNA of all four A. hydrophila isolates was amplified using the three primers and their repeatability was ascertained. The PCR cocktail consisted of Taq reaction buffer $2.5 \mu \mathrm{l}(100 \mathrm{~mm}$ Tris- $\mathrm{HCl} \mathrm{pH} 8.3$, $500 \mathrm{~mm} \mathrm{KCl}$ and $0.001 \%$ gelatin), dNTPs $-0.2 \mathrm{~mm}$, Taq DNA polymerase - 1 unit, $\mathrm{MgCl}_{2}-2 \mathrm{~mm}$, each primer - $7.5 \mathrm{pM}$ and DNA template - $30 \mathrm{ng}$ in a total reaction volume of $25 \mu \mathrm{l}$. RAPD was performed with the following parameters: an initial denaturation cycle of $95^{\circ} \mathrm{C}, 5 \mathrm{~min}$; followed by 45 cycles of denaturation at $94^{\circ} \mathrm{C}, 1 \mathrm{~min}$; primer annealing at $36^{\circ} \mathrm{C}, 1 \mathrm{~min}$ and primers extension at $72^{\circ} \mathrm{C}, 4 \mathrm{~min}$ with final extension at $72^{\circ} \mathrm{C} 12 \mathrm{~min}$.

Screening for virulence genes in A. hydrophila NPAH-1

A. hydrophila (NPAH-1) isolate was screened for presence of virulence genes viz., enterotoxins (alt), aerolysin (aerA), outer membrane proteins (aha1 and omp TS) and also heamolysin (hem). The primer details and PCR conditions used for screening the five virulence genes of $A$. hydrophila are given in the Table 1 . 
Phenotypic expression of virulence of A. hydrophila (NPAH-1)

Luria-Bertani (LB) agar containing 5\% (v/v) sheep blood was used to determine the haemolytic activity of A. hydrophila (NPAH-1). Further, bacterial extracellular products (ECP, prepared following the cellophane overlay technique as per Liu, 1957) was exposed to GFF cell line, to determine the cytotoxicity of the bacteria. Morphological changes of infected GFF cells were observed at regular intervals for 4 days post-inoculation (dpi).

\section{Experimental challenge trials}

A total of 50 healthy goldfishes (mean weight $20.6 \mathrm{~g}$ \pm 1.65 ) were used for infection experiments. Fish were maintained in 5001 capacity glass aquaria containing $3001 \mathrm{UV}$ treated water. Continued aeration was provided with $50 \%$ of water exchange daily. Water temperature in the tanks was recorded twice daily which ranged from 26 to $29^{\circ} \mathrm{C}$. The fish were acclimatised for 15 days in the laboratory, before challenge studies. Fifty fishes were divided into five experimental groups. The experimental animals were anaesthetised using MS-222 (Sigma), at 75 to $150 \mu \mathrm{g} \mathrm{l} \mathrm{l}^{-1}$ of water for 2-5 min. Each group was injected intramuscularly (i/m) with $100 \mu$ l of one of the 4 bacterial strains of $P$. shigelloides (NPPS-1), A. hydrophila (NPAH-1), C. freundii (NPCF -1) and Acinetobacter spp. (NPA-1) isolated from diseased goldfish and the fifth group which served as control were injected with $100 \mu \mathrm{l}$ sterile phosphate buffered saline (PBS). The inocula of all the seven bacterial isolates were prepared as follows: A single colony of each bacterial isolate was inoculated in $5 \mathrm{ml}$ of TSB and incubated at $28^{\circ} \mathrm{C}$ overnight and the bacterial cell density was determined by plate count method prior to challenging. The bacterial broth was centrifuged at $300 \mathrm{~g}$ for $10 \mathrm{~min}$. The cell pellets were suspended in sterile PBS and serially diluted upto $10^{-7}$ and cell counts were determined on plate count agar. Fishes were monitored for 15 days post-challenge and mortalities were recorded. Mortalities were considered to be due to the bacterial inoculation, only when the bacterial strain was reisolated in pure culture from internal organs (kidney, spleen, liver).

Calculation of $L D_{50}$ in vivo

The virulence of the A. hydrophila (NPAH-1) was further explored in vivo based on $50 \%$ lethal dose $\left(\mathrm{LD}_{50}\right)$ in gold fish. For determination of $50 \%$ lethal dose $\left(\mathrm{LD}_{50}\right)$, intramuscular injection of $0.1 \mathrm{ml}$ bacterial suspension each of $10^{4}, 10^{5}, 10^{6}$ and $10^{7} \mathrm{CFU}$ per fish was employed, in groups of 10 fishes each. Control group comprising 10 fish were injected with $0.1 \mathrm{ml}$ each of normal saline. Morbidity and mortality of the injected fishes were observed daily for a week and the affected animals were subjected for routine bacteriological examination. Reed and Muench (1938) methodology was followed to calculate $\mathrm{LD}_{50}$ value of $A$. hydrophila NPAH-1.

\section{Antibiotic susceptibility}

Standard procedure of disc diffusion method as per the guidelines of the Clinical and Laboratory Standards Institute (CLSI, 2009) was employed for determining the antibiotic susceptibility of $A$. hydrophila (NPAH-1). Antibiotic discs used in this study were procured from HiMedia Laboratories, India. A total of 16 antimicrobials agents viz., Cefixime, Chloramphenicol, Bacitracin, Nitrofurantoin, Azithromycin, Erythromycin, Gentamicin, Kanamycin, Cefalexin, Oxytetracycline, Ciprofloxacin, Amoxycillin, Enrofloxacin, Furazolidone, Ampicillin and Cifixime/Clavulanic acid were tested. By measuring the diameter of the clearance zones $(\mathrm{mm})$ around the disc, antibiotics were interpreted as sensitive, resistant and intermediate using CLSI criteria (CLSI, 2009) and criteria set by the manufacturer.

\section{Results and discussion}

\section{Viral pathogens screening}

No cytopathic effect in GFF cell line was observed upto 2 weeks after inoculating tissue homogenates and also even after 5 blind passages. No amplifications in PCR and RT-PCR for KHV, CyHV-2 and SVCV were observed from the GFF cell line supernatant and all the pooled samples were also found negative for KHV, CyHV-2 and SVCV through PCR and RT PCR. The respective positive control for the KHV, CyHV-2 and SVCV successfully produced amplification for the target gene fragments.

\section{Bacterial isolation and identification}

It has been known for decades that the motile aeromonads cause diseases among freshwater fishes. The interactions of fishes with Aeromonas spp. in aquatic environments are continual and enable the bacteria to be an opportunistic pathogen (Ottaviani et al., 2011). A. hydrophila have been a major causative agent for fish bacterial disease outbreaks around the world, resulting in enormous economic losses (Janda and Abbott, 2010). Virulent A. hydrophila were more frequently isolated from diseased fish than from healthy fish (Nielsen et al., 2001). In the present study, four isolates of A. hydrophila (NPAH-1, 2, 3, 4) along with three more bacteria viz., P. shigelloides (NPPS-1), C. freundii (NPCF-1) and Acinetobacter spp. (NPA-1) were recovered from gills, fin, heart, kidney and spleen of diseased goldfish from four ornamental fish farms in Kerala and confirmed by both traditional biochemical methods and 16S rRNA gene PCR amplification. The details of the farms and bacteria isolated from different farms are given in Table 2. The biochemical 
Table 2. Details of sample collection and bacteria isolated from the affected farms

\begin{tabular}{|c|c|c|c|c|}
\hline Farm & GPS co-ordinates & Date of collection & No. of fishes collected & Bacteria isolated \\
\hline 1 & $10^{\circ} 04^{\prime} 06.5^{\prime \prime} \mathrm{N} 76^{\circ} 31^{\prime} 04.2^{\prime \prime} \mathrm{E}$ & 02.11 .2016 & 15 & Aeromonas hydrophila (NPAH-1) \\
\hline 2 & $10^{\circ} 04^{\prime} 14.1^{\prime \prime} \mathrm{N} 76^{\circ} 31^{\prime} 02.8^{\prime \prime} \mathrm{E}$ & 08.11 .2016 & 8 & $\begin{array}{l}\text { Plesiomonas shigelloides (NPPS-1) } \\
\text { and Aeromonas hydrophila (NPAH- 2) }\end{array}$ \\
\hline 3 & $10^{\circ} 04^{\prime} 02^{\prime \prime} \mathrm{N} 76^{\circ} 31$ '21.2”'E & 08.11 .2016 & 10 & $\begin{array}{l}\text { Acinetobacter (NPA-1) and } \\
\text { Aeromonas hydrophila (NPAH-3) }\end{array}$ \\
\hline 4 & $10^{\circ} 03^{\prime} 58.4^{\prime \prime} \mathrm{N} 76^{\circ} 29^{\prime} 15.3^{\prime \prime} \mathrm{E}$ & 11.11 .2016 & 12 & $\begin{array}{l}\text { Citrobacter freundii (NPCF-1) and } \\
\text { Aeromonas hydrophila (NPAH-4) }\end{array}$ \\
\hline
\end{tabular}

tests for seven different bacterial isolates from diseased goldfish were compared with respective type strains (Table 3). The $16 \mathrm{~S}$ rRNA 1450 bp products of all 4 isolates were sequenced and they were aligned with BLAST and RDP. The RDP results showed 98.6\% homology with A. hydrophila, $98.8 \%$ homology with Acinetobacter spp., $99.3 \%$ homology with $C$. freundii and $99.1 \%$ similarity with $P$. shigelloides of the respective bacteria isolated in this study. The bacterial isolates were confirmed as P. shigelloides, $A$. hydrophila, $C$. freundii and Acinetobacter spp. and the sequences were submitted to GenBank, NCBI under the accession numbers KT361192, KT361193, KT361194 and KT361195 respectively.
Sequencing of gyrB and rpoD genes for molecular identification of $A$. hydrophila was also carried out. Even though, sequence analysis of $16 \mathrm{~S}$ rRNA is the recommended criterion for the delineation of a bacterial species (Moore et al., 1996; Bennasar et al., 1998) and for bacterial identification, the 16S rRNA gene sequence projects high similarity among Aeromonas spp. (Soler et al., 2004). For example, A. aquariorum has been often mistakenly identified as $A$. hydrophila or $A$. caviae due to the matching results obtained by $16 \mathrm{~S}$ rRNA sequences and biochemical profiles among these three species (Figueras et al., 2011) and so $16 \mathrm{~S}$ rRNA gene sequences alone for speciation of the aeromonads is controversial. The

Table 3. Biochemical characteristics of the four bacterial strains isolated from diseased goldfish in the present study, along with characteristics of reference strains

\begin{tabular}{|c|c|c|c|c|c|c|c|c|}
\hline \multirow[t]{2}{*}{ Biochemical tests } & \multicolumn{2}{|c|}{ Plesiomonas shigelloides } & \multicolumn{2}{|c|}{ Aeromonas hydrophila } & \multicolumn{2}{|c|}{ Citrobacter freundii } & \multicolumn{2}{|c|}{ Acinetobacter sp } \\
\hline & NPPS-1 & Krovaceka et al. (2000) & NPAH-1 & Chen et al. (2012) & NPCF-1 & Brenner et al. (1993) & NPA-1 & Constantiniu et al. (2004) \\
\hline Colony morphology & $\begin{array}{l}\text { Round, } \\
\text { mucoid, milk } \\
\text { white and } \\
\text { elevated }\end{array}$ & & $\begin{array}{l}\text { Pin head } \\
\text { sized, } \\
\text { round, semi } \\
\text { translucent, } \\
\text { yellowish and } \\
\text { flattened }\end{array}$ & & $\begin{array}{l}\text { Smooth, } \\
\text { opaque and } \\
\text { moist }\end{array}$ & & $\begin{array}{l}\text { Smooth } \\
\text { and pale }\end{array}$ & \\
\hline Gram's staining & - & - & - & - & - & - & - & - \\
\hline Catalase & + & + & + & + & & + & + & + \\
\hline Oxidase & + & + & t & + & - & - & - & - \\
\hline Motility & + & + & + & + & + & + & & - \\
\hline Indole & & - & + & + & & - & & \\
\hline Urease & - & - & - & - & - & - & & \\
\hline Simmon's citrate & & - & + & + & + & + & + & + \\
\hline Methyl red & + & + & + & + & + & + & & - \\
\hline Voges Proskauer & & - & + & + & - & - & - & - \\
\hline Lysine decarboxylase & + & + & + & + & & - & & \\
\hline Ornithine decarboxylase & + & + & - & - & - & - & & \\
\hline Glucose & & t & t & + & t & + & + & + \\
\hline Glycerol & + & + & + & + & + & + & & \\
\hline Inositol & + & + & - & - & - & - & & \\
\hline Lactose & + & t & t & + & + & + & + & + \\
\hline Maltose & + & + & + & + & & & + & + \\
\hline Raffinose & - & - & - & - & + & + & & \\
\hline Rhamnose & - & - & - & - & & & & \\
\hline Sorbitol & - & - & - & - & + & + & & \\
\hline Xylose & - & - & - & - & + & + & & \\
\hline
\end{tabular}


benefits of housekeeping genes have been well studied in recent times (e.g., gyrB and $\mathrm{rpoD}$ ) in the identification of Aeromonas spp. (Soler et al., 2004). Among all Aeromonas spp., the sequencing of the house keeping genes has revealed a higher sequence divergence than that of the $16 \mathrm{~S}$ rRNA sequence (Kupfer et al., 2006). In our work, when the phylogenetic tree was constructed using the nucleotide sequences of $16 \mathrm{~S}$ rRNA gene and housekeeping genes sequences, the four strains of $A$. hydrophila (NPAH-1, 2, 3 and 4) recovered from the moribund ornamental fishes were found phylogenetically related to A. hydrophila (Fig. 1a). The overall nucleotide sequence similarity of gyrB and rpoD genes of all the four A. hydrophila isolates ranged between 98.9 and $99.2 \%$. GyrB and rpoD gene

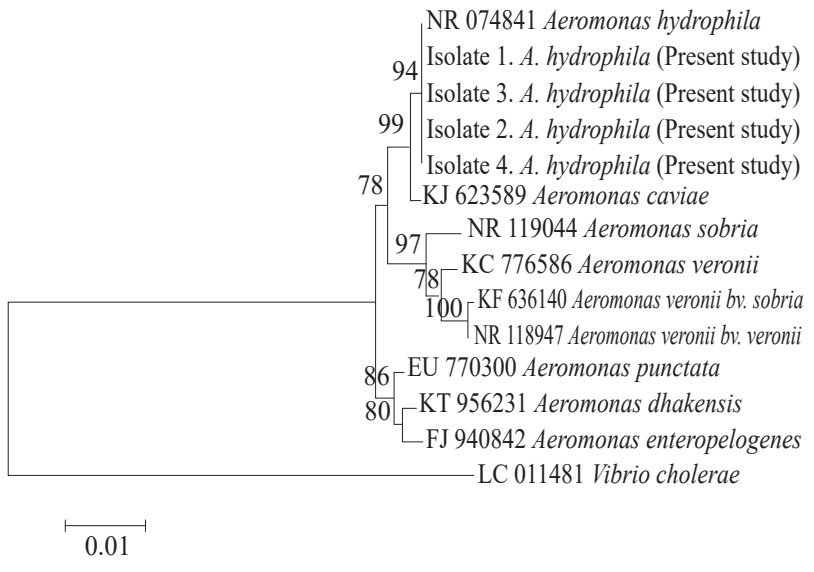

(a) sequences of four strains of $A$. hydrophila were used for the phylogenetic tree construction, with their most similar matches in the GenBank database and the sequences were submitted to NCBI GenBank (Fig. 1b and c).

\section{RAPD profile}

Amplification of the DNA from each of 4 A. hydrophila isolates with the three random primers OPA-2, OPA-3 and OPA-4 produced amplicons, which were consistent and appeared as distinct bands on agarose gel after electrophoresis. The RAPD patterns of all 4 isolates of A. hydrophila were similar and therefore referred to as genetically related. The fingerprints pattern generated by 3 random primers viz., OPA-2, OPA-3 and OPA-4 of

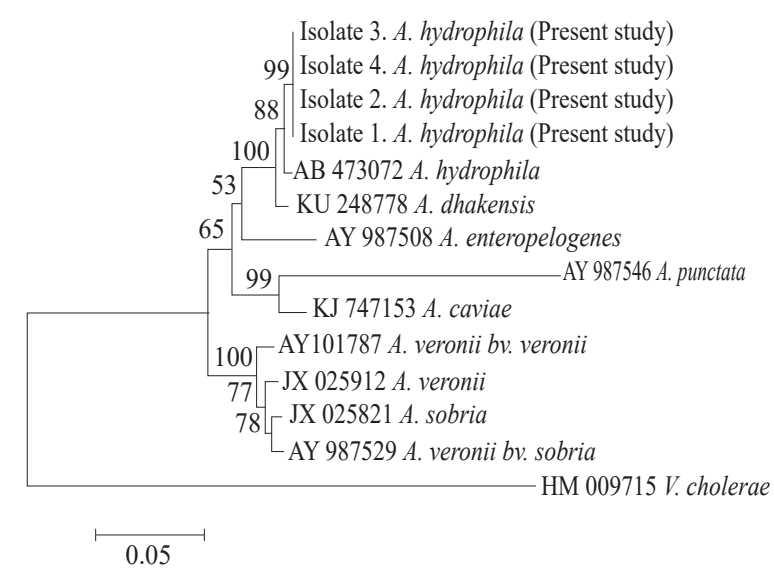

(b)

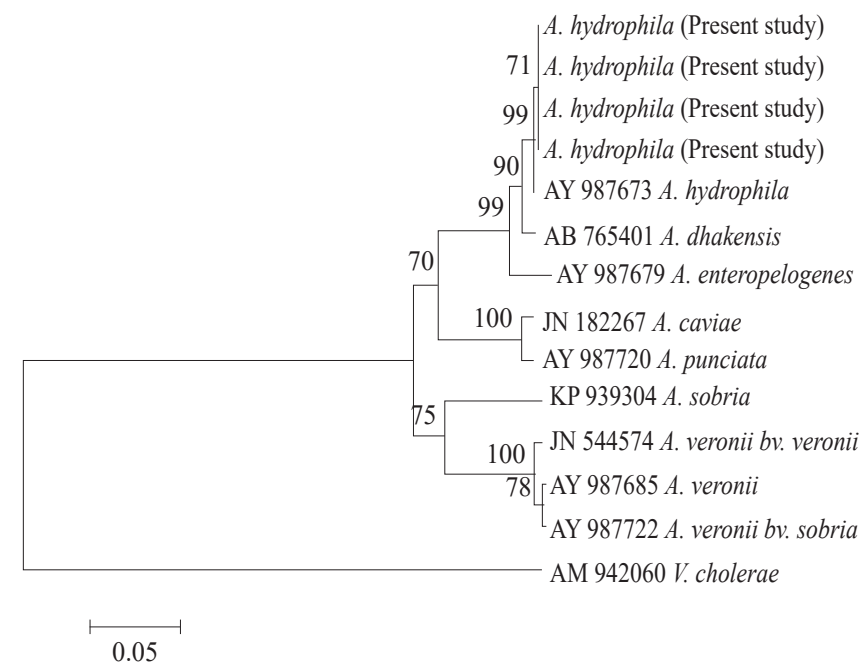

(c)

Fig. 1. Phylogenetic tree based on the nucleotide sequences of 16S rRNA (Fig. 1a), gyrB (Fig 1b) and rpoD (Fig 1c) of four isolates of A. hydrophila (NPAH-1, 2, 3 and 4) and related Aeromonas spp. The tree was constructed by neighbour-joining algorithms with genetic distance computed by Kimura's 2-parameter method. Bootstrap values of 1000 simulations are indicated at the branches. The bar indicates percentage difference. 
the isolates contained 5 to 12 bands ranging from 400 to $3530 \mathrm{bp}$ (Fig. 2). In our study, all isolates showed uniformity in biochemical characteristics and RAPD pattern. Therefore, we randomly selected one representative strain (A. hydrophila, NPAH-1) for screening virulence genes, cytotoxicity analysis, antibiotic sensitivity assay and for the experimental challenge trial.

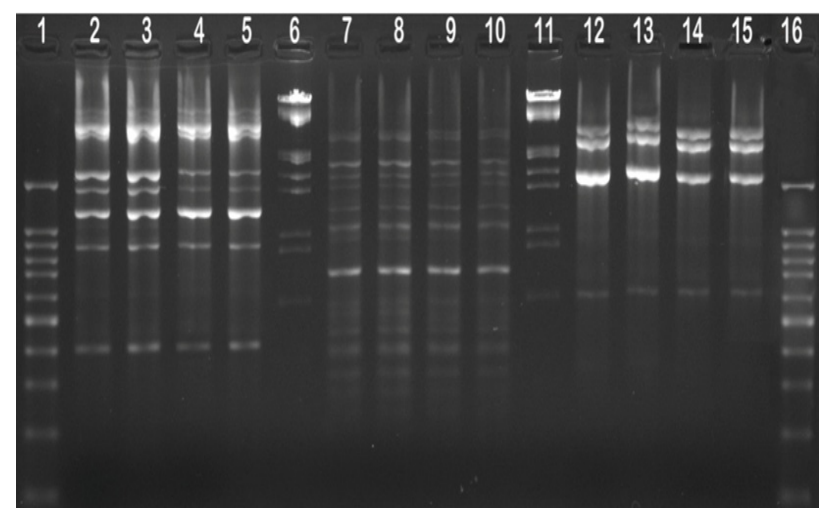

Fig. 2. RAPD profiles of A. hydrophila (NPAH-1, 2, 3 and 4) isolated from goldfish.

The profiles were generated using 3 primers (OPA-2, OPA-3 and OPD-4). Lane 1: 100 bp to 1500 bp ladder (Origin, India); Lane 2-5: RAPD profile of NPAH-1, 2, 3 and 4 of using OPD-2; Lane 6: Lamda DNA/EcoRI Hind III double digest (GeNei); Lane 7-10: RAPD profile of NPAH-1, 2, 3 and 4 using OPD-3; Lane 11: Lamda DNA/EcoRI Hind III double digest (GeNei); Lane 12-15: RAPD profile of NPAH-1, 2, 3 and 4 using OPD-4; Lane 16: 100 bp to 1500 bp ladder (Origin, India)

\section{Virulence genes}

Pathogenesis of Aeromonas spp. has been believed to be caused by multi-factorial toxins, such as enterotoxin and extracellular products (Sha et al., 2002; Janda and Abbott, 2010). Therefore, these virulence factor encoding genes have been applied for evaluating the pathogenicity of Aeromonas spp. isolated from different sources viz., environment, foodstuffs, fish, human and aquatic environments (Ottaviani et al., 2011; Puthucheary et al., 2012). The identification and examination of virulence genes is a prerequisite to understand the pathogenicity mechanisms of an organism (Strauss and Falkow, 1997). The Aeromonas strains isolated either from diseased fish or healthy fish and water samples often had number of virulence genes in different combinations (Santos et al., 1999; Sreedharan et al., 2012). A variety of toxins are secreted by aeromonads that boosts the severity of many infections (Cahill, 1990; Vadivelu et al., 1995; Chopra and Houston, 1999; Sen and Rodgers, 2004). However, not all species of aeromonads produce all the toxins (Chopra and Houston 1999). PCR amplification and sequencing of the genes for virulence factors viz., hemolysin gene, aerolysin gene (aerA), cytotonic enterotoxin gene (alt), adhesion gene ( $a h a 1)$ and outer membrane protein (omp TS) from the $A$. hydrophila (NPAH-1) isolate was attempted and the expected PCR products of size $963 \mathrm{bp}, 720 \mathrm{bp}, 480 \mathrm{bp}$, $1087 \mathrm{bp}$ and $1002 \mathrm{bp}$ respectively were obtained (Fig. 3) and the sequences were submitted to NCBI GenBank (Accession nos.: KU527552, KU527544, KU527550, KU527545 and KU527551 respectively). In agreement with previous studies (Hu et al., 2012; Yi et al., 2013), we found expression of 5 different virulence genes in the tested isolate.

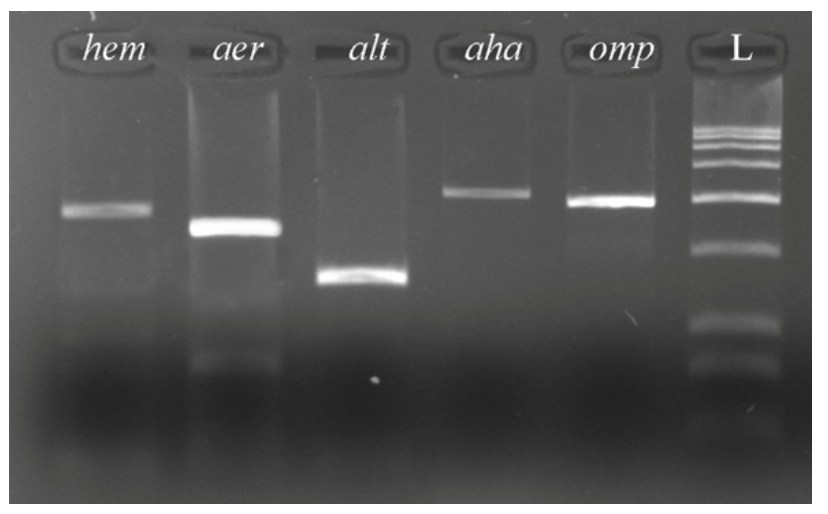

Fig. 3. Detection and identification of $A$. hydrophila (NPAH-1) virulence genes by amplification of fragments in the PCR assay.

Lane 1: hem; Lane 2: aerA; Lane 3: alt; Lane 4: aha1; Lane 5: omp TS; Lane 6: Low range DNA ruler $100 \mathrm{bp}$ to $3 \mathrm{kbp}(\mathrm{GeNei})$

Phenotypic expression of virulence by invitro assay of A. hydrophila (NPAH-1)

In the present study, $A$. hydrophila (NPAH-1) was found haemolytic on goat blood agar and produced $\beta$ haemolysis (Fig 4). When ECP from A. hydrophila (NPAH-1) was tested on GFF cell line (Fig. 5a) signs of cytotoxicity including dislodgement of cells, rounding and shrinkage of cytoplasm were observed, which directly correlates with the virulence of $A$. hydrophila isolate. The changes indicating cytotoxicity started in GFF cells by $1 \mathrm{dpi}$ and death of the cells appeared on $3 \mathrm{dpi}$ (Fig. 5b).

\section{Experimental challenge trials}

The differentiation of pathogenic strains from non-pathogens is inevitable in pathological investigations. In the experimental challenge, cumulative mortality rate of $100 \%$ was reached in goldfish injected with overnight grown $A$. hydrophila (NPAH-1). The experimentally infected goldfish displayed clinical signs of scale protrusion, distended abdomen, tail rot and haemorrhages 


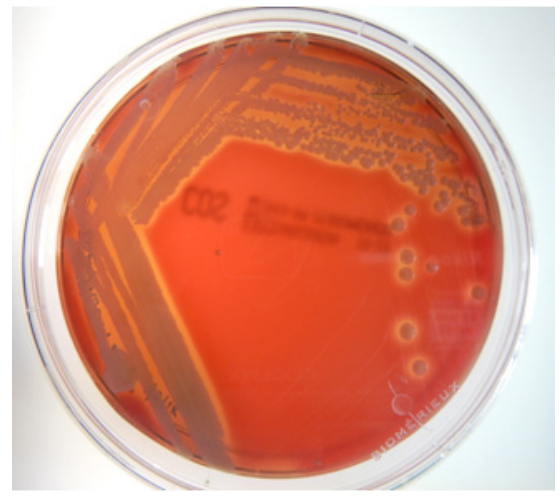

Fig. 4. $\beta$ haemolytic colonies of A. hydrophila (NPAH-1) on $5 \%$ goat blood agar

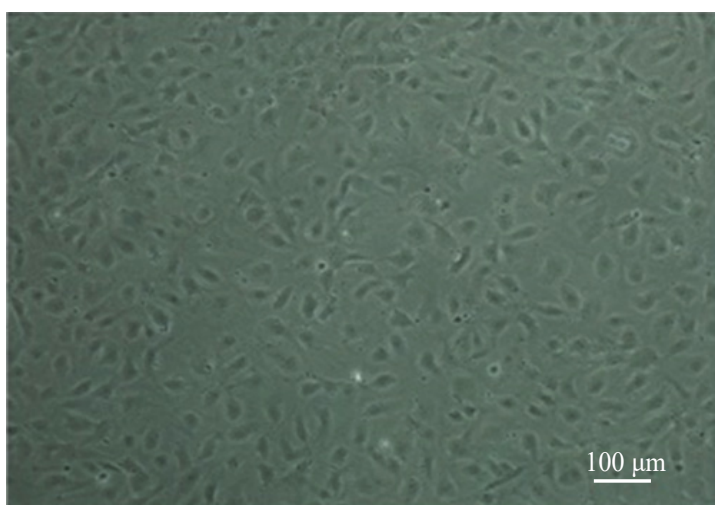

(a) results showed that mortality of the fishes in the farm were mainly due to $A$. hydrophila. The other three bacteria viz., NPPS-1, NPCF-1, NPA-1 were found to be secondary bacterial pathogens.

$L D_{50}$ in vivo

In general bacterial isolates are grouped as virulent, weakly virulent and avirulent according to the $\mathrm{LD}_{50}$ values $10^{4.5-5.5}, 10^{5.5-6.5}$ and $>10^{7} \mathrm{cfu} \mathrm{ml}^{-1}$ respectively (Lallier and Daigneault, 1984). While calculating $\mathrm{LD}_{50}$ values of A. hydrophila (NPAH-1), the cumulative mortality rates of $12-21 \%, 34-48 \%, 62-90 \%$ and $100 \%$ were recorded in goldfish injected at doses of $1 \times 10^{4}, 1 \times 10^{5}, 1 \times 10^{6}$ and $1 \times 10^{7}$ CFU per fish, respectively. $\mathrm{LD}_{50}$ value was estimated as

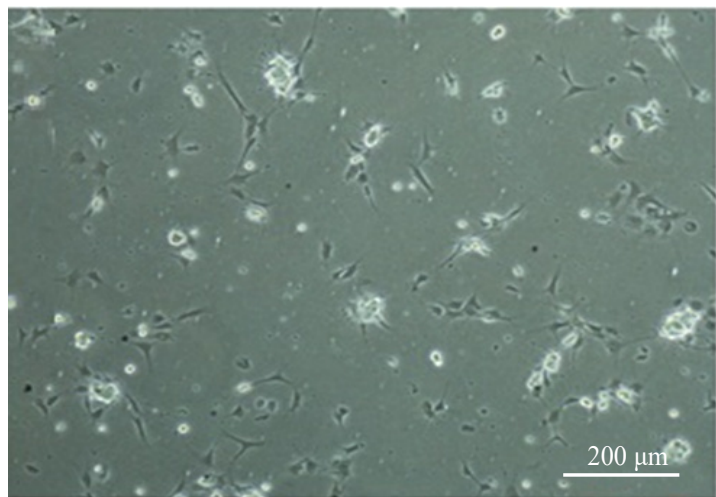

(b)

Fig. 5. Cytotoxicity of ECP of $A$. hydrophila (NPAH-1) on GFF cell line. (a) Uninoculated GFF cell line (control); (b) GFF cell line subsequent to addition of ECP from $A$. hydrophila (NPAH-1) isolated from goldfish

on tail as reported in the naturally affected goldfish collected from the farms (Fig. 6a, b). No mortality was observed in the group receiving bacterial isolates NPPS-1, NPCF-1, NPA-1 and control group up to 15 days postchallenge. Pure bacterial colonies recovered from the liver and kidney of all freshly dead fish exhibited homologous biochemical characteristics with the original isolate. The

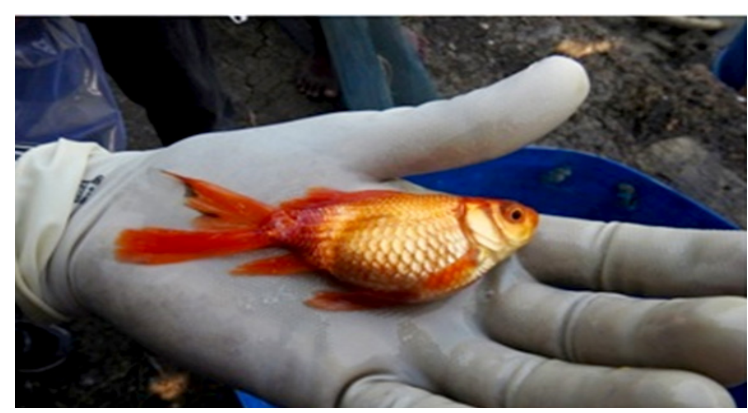

(a)
$10^{5.35} \mathrm{CFU}$ per fish. In most animals, distended abdomen, scale protrusion, tail rot, haemorrhages on tail and scale loss were also noticed finally leading to fish death in 1 week.

\section{Antibiotic sensitivity}

Various studies have reported antimicrobial resistance in bacteria isolated from ornamental

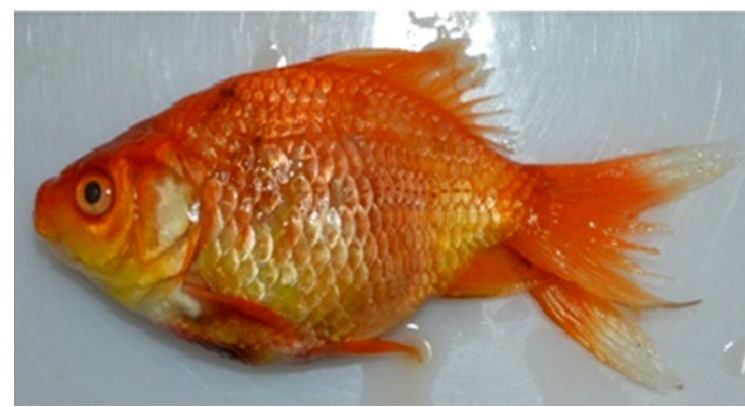

(b)

Fig. 6. Clinical signs viz., distended abdomen, scale protrusion, tail rot and haemorrhages on body of affected goldfish. (a) Infected goldfish collected from the affected farm; (b) Goldfish experimentally challenged with A. hydrophila (NPAH-1) 
fish and their environment (Verner-Jeffreys et al., 2009; Cizek et al., 2010; Dias et al., 2012). A. hydrophila (NPAH-1) strain was screened for antibiotic susceptibility using the agar diffusion method and the results are shown in Table 4. A. hydrophila (NPAH-1) was found resistant with minimum stress conditions. Maintenance of good water quality and minimum stress are essential for the survival as well for the optimum growth of cultured organisms. Overall, the results obtained highlight the need to promote responsible ornamental fish farming, good

Table 4. Antibiotic sensitivity pattern of Aeromonas hydrophila (NPAH-1) isolate

\begin{tabular}{|c|c|c|c|}
\hline Antibiotics & Concentration $\left(\mu \mathrm{g} \mathrm{disc} \mathrm{di}^{-1}\right)$ & Inhibition zone (mm) & Inference \\
\hline Cefixime & 5 & 25 & $\mathrm{~S}$ \\
\hline Chloramphenicol & 25 & 22 & $\mathrm{~S}$ \\
\hline Bacitracin & 10 & No zone & $\mathrm{R}$ \\
\hline Nitrofurantoin & 100 & 19 & $\mathrm{~S}$ \\
\hline Azithromycin & 30 & 12 & $\mathrm{R}$ \\
\hline Erythromycin & 10 & 11 & $\mathrm{I}$ \\
\hline Gentamicin & 120 & 13 & $\mathrm{I}$ \\
\hline Kanamycin & 30 & 20 & $\mathrm{~S}$ \\
\hline Cefalexin & 30 & No zone & $\mathrm{R}$ \\
\hline Oxytetracycline & 30 & 17 & $\mathrm{I}$ \\
\hline Ciprofloxacin & 30 & 21 & $\mathrm{~S}$ \\
\hline Amoxycillin & 25 & No zone & $\mathrm{R}$ \\
\hline Enrofloxacin & 10 & 13 & $\mathrm{R}$ \\
\hline Furazolidone & 100 & 18 & $\mathrm{~S}$ \\
\hline Ampicillin & 25 & 11 & $\mathrm{R}$ \\
\hline Cifixime / Clavulanic acid & $5 / 10$ & 21 & $\mathrm{~S}$ \\
\hline
\end{tabular}

R: Resistant; S: Sensitive; I: Intermediate sensitive

(R) to six antibiotics viz., Bacitracin, Azithromycin, Cefalexin, Amoxycillin, Enrofloxacin and Ampicillin. The strain was intermediate (I) sensitive to Erythromycin, Gentamicin and Oxytetracycline while susceptible to Cefixime, Chloramphenicol, Nitrofurantoin, Kanamycin, Ciprofloxacin, Furazolidone and Cifixime/Clavulanic acid. Resistance to these antibiotics has likely resulted from their indiscriminate use in the aquarium fish industry to treat diseases, while resistance can also result from gene mutations or by acquisition of transferable genetic elements (Jacobs and Chenia, 2007).

Intramuscular injection of Ciprofloxacin at a dose of $10 \mathrm{mg} \mathrm{kg}^{-1}$ body weight for five days was advised to all the fish farms. After the antibiotic treatment, the fish recovered from haemorrhages on the tail, fin, dropsy and no further mortality of fishes was noticed in the farms.

The present study highlights $A$. hydrophila could potentially be associated with bacterial infection in goldfish. A. hydrophila NPAH-1 isolates harbour multiple virulence genes with multiple antibiotic resistance. These might be a possible reason for treatment failures in fish disease outbreaks. The A. hydrophila isolated in the present study could be proliferative in the fish during stress conditions. Therefore to avoid bacterial disease outbreaks, ornamental fish farms should be maintained husbandry practices and prudent use of antimicrobials in the ornamental fish industry.

\section{Acknowledgements}

The authors are thankful to the Director General, ICAR and DDG (Fy) ICAR, New Delhi, India for their support, encouragement and guidance. We thank Rahul G. Kumar, PMFGR Centre of ICAR-NBFGR, Kochi for his critical inputs during the preparation of the manuscript.

\section{References}

Austin, B. and Austin, D. 2007. Bacterial fish pathogens: Diseases of farmed and wild fish, $4^{\text {th }}$ edn. Praxis Publishing Ltd., Chichester, UK.

Ayyappan, S., Jena, J. K., Gopalakrishnan, A. and Pandey, A. K. 2006. Handbook of fisheries and aquaculture. Directorate of Information and Publications of Agriculture, Indian Council of Agricultural Research, New Delhi, 22, 354 pp.

Barrow, G. I. and Feltham, R. K. A. 2004. Cowan and Steel's manual for the identification of medical bacteria. Cambridge University Press, UK.

Bennasar, A., Guasp, J. and Lalucat, J. 1998. Molecular methods for the detection and identification of Pseudomonas stutzeri in pure culture and environmental samples. Microb. Ecol., 35(1): 22-53. DOI:10.1007/s002489900057. 
Bercovier, H., Fishman, Y., Nahary, R., Sinai, S., Zlotkin, A., Eyngor, M., Gilad, O., Eldar, A. and Hedrick, R. P. 2005. Cloning of the koi herpesvirus (KHV) gene encoding thymidine kinase and its use for a highly sensitive PCR based diagnosis. BMC Microbiol., 5(1): 1-9. doi.org/10.11 86/1471-2180-5-13.

Brenner, D. J., Grimont, P. A. D., Steigerwalt, A. G., Fanning, G. R., Ageron, E. and Riddle, C. F. 1993. Classification of Citrobacteria by DNA hybridisation: Designation of Citrobacter famzeri sp. nov., Citrobacter youngae sp. nov., Citrobacter braakii sp. nov., Citrobacter werkmanii sp. nov., Citrobacter sedlakii sp. nov. and three unnamed Citrobacter genomospecies. Int. J. Syst. Bacteriol., 43(4): 645-658. DOI: 10.1099/00207713-43-4-645.

Cahill, M. M. 1990. Virulence factors in motile Aeromonas species: a review. J. Appl. Bacteriol., 69(1): 1-16.

Chen, Y. F., Liang, R. S., Zhuo, X. L., Wu, X. T. and Zou, J. X. 2012. Isolation and characterisation of Aeromonas schubertii from diseased snakehead, Channa maculata (Lacepede). J. Fish. Dis., 35(6): 421-430.

Chopra, A. K. and Houston, C. W. 1999. Enterotoxins in Aeromonas-associated gastroenteritis. Microbes Infec., 1(13): 1129-1137. doi.org/10.1016/S1286-4579(99)00202-6.

Cízek, A., Dolejska, M., Sochorova, R., Strachotova, K., Piackova, V. and Vesely, T. 2010. Antimicrobial resistance and its genetic determinants in aeromonads isolated in ornamental (koi) carp (Cyprinus carpio koi) and common carp (Cyprinus carpio). Vet. Microbiol., 142(3): 435-439. doi: 10.1016/j.vetmic.2009.10.001.

CLSI 2009. Methods for dilution antimicrobial susceptibility tests for bacteria that grow aerobically:Approved standard. CLSI document M07-A8, Clinical and Laboratory Standards Institute, Wayne, PA.

CLSI 2009. Performance standards for antimicrobial susceptibility testing, $21^{\text {st }}$ Informational supplement. CLSI M100-S21. Clinical and Laboratory Standards Institute, Wayne, PA.

Constantiniu, S., Romaniuc, A., Iancu, L. S., Filimon, R. and Tarasi, I. 2004. Cultural and biochemical characteristics of Acinetobacter spp. strains isolated from hospital units. J. Prev. Med., 12: 35-42.

Das, B. K., Mukherjee, S. C., Sahuand, B. B. and Murjani, G. 1999. Neem (Azadirachta indica) extracts as an antibacterial agent against fish pathogenic bacteria. Ind. J. Exp. Biol., 37: 1097-1100.

Dias, C., Mota, V., Martinez-Murcia, A. and Saavedra, M. J. 2012. Antimicrobial resistance patterns of Aeromona spp. solated from ornamental fish. J. Aquac. Res. Develop., 3(3): 131. DOI: 10.4172/2155-9546-C1-021.

Figueras, M. J., Beaz-Hidalgo, R., Senderovich, Y., Laviad, S. and Halpern, M. 2011. Re-identification of Aeromonas isolates from chironomid egg masses as the potential pathogenic bacteria Aeromonas aquariorum. Environ. Microbiol. Rep., 3(2): 239-244. doi.org/10.1111/j.1758-22 29.2010.00216.x.
Hu, M., Wang, N., Pan, Z. H., Lu, C. P. and Liu, Y. J. 2012. Identity and virulence properties of Aeromonas isolates from diseased fish, healthy controls and water environment in China. Lett. Appl. Microbiol., 55(3): 224-233. doi: 10.11 11/j.1472-765X.2012.03281.x. Epub 2012 Jul 20.

Jacobs, L. and Cheni, H. Y. 2007. Characterisation of integrons and tetracycline resistance determinants in Aeromonas spp. isolated from South African aquaculture systems. Int. J. Food Microbiol., 114(3): 295-306. DOI: 10.1016/j. ijfoodmicro.2006.09.030.

Janda, J. M. and Abbott, S. L. 2010. The genus Aeromonas: taxonomy, pathogenicity and infection. Clin. Microbiol. Rev., 23(1): 35-73. doi: 10.1128/CMR.00039-09.

Jeffery, K. R., Bateman, K., Bayley, A., Feist, S. W., Hulland, J., Longshaw, C., Stone, D., Woolford, G. and Way, K. 2007. Isolation of a cyprinid herpesvirus 2 from goldfish, Carassius auratus (L.) in the UK. J. Fish. Dis., 30(11): 649-656. DOI:10.1111/j.1365-2761.2007.00847.x.

Khushiramani, R., Girisha, S. K., Karunasagar, I. and Karunasagar, I. 2007. Cloning and expression of an outer membrane protein ompTS of Aeromonas hydrophila and study of immunogenicity in fish. Protein Expres Purif., 51(2): 303-307. DOI: 10.1016/j.pep.2006.07.021.

Krovacek, K., Eriksson, L. M., Gonzalez-Rey, C., Rosinsky, J. and Ciznar, I. 2000. Isolation, biochemical and serological characterisation of Plesiomonas shigelloides from freshwater in Northern Europe. Comp. Immunol. Microbiol., 23(1): 45-51. DOI: 10.1016/S0147-9571(99)00058-2.

Kumar, R., Swaminathan, T. R., Arathi, D., Basheer, V. S. and Jena, J. K. 2015. Mass mortality in ornamental fish, Cyprinus carpio koi caused by a bacterial pathogen, Proteus hauseri. Acta Tropica, 149: 128-134. DOI: 10.1016/j. actatropica.2015.05.022

Kupfer, M., Kuhnert, P., Korczak, B. M., Peduzzi, R. and Demarta, A. 2006. Genetic relationships of Aeromonas strains inferred from 16S rRNA, gyrB and rpoB gene sequences. Int. J. Syst. Evol. Microbiol., 56(12): 2743-2751. DOI:10.1099/ijs.0.63650-0.

Lallier, R. and Daigneault, P. 1984. Antigenic differentiation of pili from non-virulent fish pathogenic strains of Aeromonas hydrophila. J. Fish. Dis., 7(6): 509-572. doi. org/10.1111/j.1365-2761.1984.tb01177.x.

Liu, P. V. 1957. Survey of haemolysin production among species of Pseudomonas. J. Bacteriol., 74(6): 718-727.

Martinez-Murcia, A. J., Monera, A., Saavedra, M. J., Oncina, R., Lopez-Alvarez, M., Lara, E. and Figueras, M. J. 2011. Multilocus phylogenetic analysis of the genus Aeromonas. Syst. Appl. Microbiol., 34(3): 189-199. doi: 10.1016/j. syapm.2010.11.014.

Miller, S. A., Dykesand, D. D. and Polesky, H. F. 1988. A simple salting out procedure for extracting DNA from human nucleated cells. Nucleic Acids Res., 16(3): 1215.

Mohanty, B. R. and Sahoo, P. K. 2007. Edwardsiellosis in fish: a brief review. J. Biosci., 32: 1331-1344. DOI:10.1007/ s12038-007-0143-8. 
Moore, E. R. B., Mau, M., Arnscheidt, A., Bottger, E. C., Hutson, R. A., Collins, M. D., Van de, Peer Y., De Wachter, R. and Timmis, K. N. 1996. The determination and comparison of the 16S rRNA gene sequence of species of the genus Pseudomonas (sensu stricto) and estimation of the natural intrageneric relationships. Syst. Appl. Microbiol., 19(4): 478-492. doi.org/10.1016/S0723-2020(96)80021-X.

Nielsen, M. E., Hoi, L., Schmidt, A. S., Qian, D., Shimada, T., Shen, J. Y. and Larsen, J. L. 2001. Is Aeromonas hydrophila the dominant motile Aeromonas species that causes disease outbreaks in aquaculture production in the Zhejiang Province of China. Dis. Aquat. Organ., 46(1): 23-29. DOI: 10.3354/dao046023.

Noga, E. J. 2010. Fish disease: Diagnosis and treatment, $2^{\text {nd }}$ edn. John Wiley \& Sons, Inc., Iowa, USA.

Omprakasam, M. and Manohar, L. 1991. Experimental infection of some bacterial fish pathogens in the cichlid fish, Oreochromis mossambicus. Ind. J. Fish., 38: 106-110.

Ottaviani, D., Parlani, C., Citterio, B., Masini, L., Leoni, F., Canonico, C., Sabatini, L. and Bruscolini, F. 2011. Putative virulence properties of Aeromonas strains isolated from food, environmental and clinical sources in Italy: a comparative study. Int. J. Food Microbiol., 144(3): 538-545. doi: 10.1016/j.ijfoodmicro.2010.11.020.

Puthucheary, S. D., Puah, S. M. and Chua, K. H. 2012. Molecular characterisation of clinical isolates of Aeromonas species from Malaysia. PLoS ONE, 7(2): e30205.

Reed, M. J. and Muench, M. 1938. A simple method for estimating fifty percent endpoints. Am. J. Hyg., 27(3): 493-497.

Santos, J. A., Gonzalez, C. J., Otero, A. and Garcia-Lopez, M. L. 1999. Haemolytic activity and siderophore production in different Aeromonas species isolated from fish. Appl. Environ. Microbiol., 65(12): 5612-5614.

Sen, K. and Rodgers, M. 2004. Distribution of six virulence factors in Aeromonas species isolated from US drinking water utilities: a PCR identification. J. Appl. Microbiol., 97(5): 1077-1086.

Sha, J., Kozlova, E. V. and Chopra, A. K. 2002. Role of various enterotoxins in Aeromonas hydrophila-induced gastroenteritis: generation of enterotoxin gene-deficient mutants and evaluation of their enterotoxic activity. Infect Immun., 70(4): 1924-1935. doi: 10.1128/IAI.70.4.19241935.2002.

Soler, L., Yanez, M. A., Chacon, M. R., Aguilera-Arreola, M. G., Catalan, V., Figueras, M. J. and Martınez-Murcia, A. J. 2004. Phylogenetic analysis of the genus Aeromonas based on two housekeeping genes. Int. J. Syst. Evol. Microbiol., 54(5): 1511-1519. DOI:10.1099/ijs.0.03048-0.

Date of Receipt : : 31.07.2017

Date of Acceptance : 03.12.2018
Sreedharan, K., Philip, R. and Singh, I. S. B. 2012. Virulence potential and antibiotic susceptibility pattern of motile aeromonads associated with freshwater ornamental fish culture systems: a possible threat to public health. Braz. J. Microbiol., 43(2): 754-765. doi: 10.1590/S151783822012000200040

Stone, D. M., Ahne, W., Denham, K. D., Dixon, P. F., Liu, C. T. Y., Sheppard, A. M., Taylor, G. R. and Way, K. 2003. Nucleotide sequence analysis of the glycoprotein gene of putative spring viraemia of carp virus and pike fry rhabdovirus isolates reveals four genogroups. Dis. Aquat. Org., 53(3): 203-210. DOI:10.3354/dao053203.

Strauss, E. J. and Falkow, S. 1997. Microbial pathogenesis: genomic and beyond. Science, 276(5313): 707-712. DOI: $10.1126 /$ science.276.5313.707.

Tamura, K., Peterson, D., Peterson, N., Stecher, G., Nei, M. and Kumar, S. 2011. MEGA5: Molecular evolutionary genetics analysis using maximum likelihood, evolutionary distance and maximum parsimony methods. Mol. Biol. Evol., 28(10): 2731-2739. doi: 10.1093/molbev/msr121.

Vadivelu, J., Puthucheary, S. D., Phillips, M. and Chee, Y. W. 1995. Possible virulence factors involved in bacteremia caused by Aeromonas hydrophila. J. Med. Microbiol., 42(3): 171-174. doi: 10.1099/00222615-42-3-171.

Verner-Jeffreys, D. W., Welch, T. J., Schwarzand, T., Pond, M. J., Woodward, M. J., Haig, S. J., Rimmer, G. S. E., Roberts, E., Morrison, V. and Austin, C. B. 2009. High prevalence of multidrug-tolerant bacteria and associated antimicrobial resistance genes isolated from ornamental fish and their carriage water. PLoS ONE, 4: e8388.

Vivekanandhan, G., Savithamani, K., Hathaand, A. A. and Lakshmanaperumalsamy, P. 2002. Antibiotic resistance of Aeromonas hydrophila isolated from marketed fish and prawn of South India. Int. J. Food Microbiol., 76(1): 165-168. DOI: 10.1016/S0168-1605(02)00009-0.

Wang, L., Wei, Y., Yuan, G., Dai, M. and Chen, X. 2012. Molecular characterisation and virulence genes of Aeromonas hydrophila isolated from the Chinese giant salamander (Andrias davidianus). Asian Herpetol. Res., 3(4): 303-309.

Weisburg, W. G., Barns, S. M., Pelletierand, D. A. and Lane, D. J. 1991. 16S ribosomal DNA amplification for phylogenetic study. J. Bacteriol., 173(2): 697-703. DOI: 10.1128/jb.1 73.2.697-703.1991.

Yi, S. W., You, M. J., Cho, H. S., Lee, C. S., Kwonand, J. K. and Shin, G. W. 2013. Molecular characterisation of Aeromonas species isolated from farmed eels (Anguilla japonica). Vet. Microbiol., 164(1): 195-200. doi: 10.1016/j. vetmic.2013.02.006. 